\title{
Prevalence of Vitamin D deficiency and associated factors in Mexican patients with allergic rhinitis and asthma
}

\author{
César I. Urquiza-Ramírez, Juan C. Fernandez de Cordova-Aguirre, Andrea A. Velasco-Medina, and \\ Guillermo Velazquez-Samano* \\ Allergy and Clinical Immunology Service, Hospital General de México, Mexico City, Mexico
}

\begin{abstract}
Introduction: The general population has impaired serum Vitamin D (VD) levels. Poor values are associated with allergic diseases. Objective: The objective of the study was to determine the prevalence of VD deficiency and associated factors in patients with allergic rhinitis and asthma. Material and methods: This is a descriptive study in children 3-14 years old, with allergic rhinitis and asthma sensitized to aeroallergens identified by skin prick tests. We measured serum 25-hydroxy VD levels and evaluated associated factors. Results: Sixty-three patients were included, with a mean age of 7.25 years old, $54 \%$ were female. Mean weight was $26.7 \mathrm{~kg}$, mean VD levels were $23.66 \mathrm{ng} / \mathrm{ml}( \pm 7.28), 22.2 \%$ had sufficient levels, $47.6 \%$ had insufficient levels, and $30.2 \%$ had deficient levels. We found an association with increased risk of VD deficiency in patients ages 12-14 years old (odds ratio [OR] 7.5, confidence interval [CI] 1.306-43.066), the skin type V with (OR 3.444, IC 2.3345.083), and the lack of consumption of cod liver supplements (OR 1.475, Cl 1.237-1.759). Conclusions: This sample of Mexican patients with allergic rhinitis and asthma showed the high prevalence of both VD deficiency and insufficiency. Consumption of cod liver supplements was a protective factor for deficiency. No association between VD deficiency and severity of allergic rhinitis and asthma was found in this sample of patients in the Mexican General Hospital of Mexico.
\end{abstract}

Key words: Vitamin D deficiency. Asthma. Allergic rhinitis.

\section{Introduction}

Vitamin D (VD) has been described as an essential element in the maintenance of mineral homeostasis and bone architecture $(\mathrm{X})$; however, the vision on the physiological functions of said nutrient has changed radically, the discovery of the VD receptor in immune system cells initiated a series of investigations related to the regulatory activity of this vitamin toward inflammatory phenomena and the association between low levels and development of various infectious and degenerative pathologies. Interest in VD has increased considerably because of multiple studies show that between 30 and $50 \%$ of the general population have serum VD deficiency ${ }^{1,2}$. In Mexico, Flores et al. report a prevalence of VD deficiency of $10-24 \%$ and $18-30 \%$ of insufficiency in children ${ }^{3}$. Ninety percent of VD requirements are synthesized through proper skin exposure to sunlight; the remaining $10 \%$ is obtained from food ${ }^{4,5}$

The main cause of VD deficiency is inadequate sunlight exposure. Sunscreen use reduces its synthesis more than $95 \%$. People with dark skin tone require at least 3-5 times more sun exposure to produce the same amount of VD that a person with white skin tone. There is an inverse association with body mass index (BMI) because more than $30 \mathrm{~kg} / \mathrm{m}^{2}$ values are associated with deficiency. Other causes include malabsorption syndromes, nephrotic
Correspondence:

*Guillermo Velazquez-Samano

E-mail: gvelazquezsamano@yahoo.com DOI: 10.24875/HGMX.20000083 0185-1063/@ 2020 Sociedad Médica del Hospital General de Mexico.
NC-ND license (http://creativecommons.org/licenses/by-nc-nd/4.0/).
Date of reception: 24-10-2019

Date of acceptance: 01-04-2020
Available online: $21-07-2020$ Rev Med Hosp Gen Mex. 2020;83(3):113-119 www.hospitalgeneral.mx 
syndrome (a case in which one loses VD bound proteins through urine), anticonvulsants, antiretrovirals, and chronic use of systemic corticosteroids 6 . Endocrinology guidelines for assessment, treatment, and prevention of deficiency suggest that $25(\mathrm{OH}) \mathrm{VD}$ can be measured to evaluate blood levels of $\mathrm{VD}^{6}$. An optimal level is defined between 40 and $60 \mathrm{ng} / \mathrm{ml}$, sufficiency between 30 and 39 $\mathrm{ng} / \mathrm{ml}$, insufficiency between 21 and $29 \mathrm{ng} / \mathrm{ml}$, and deficiency $<20 \mathrm{ng} / \mathrm{ml}^{7}$.

The association between VD levels and respiratory allergic diseases such as asthma and rhinitis has been investigated. Some studies have associated levels $<30$ $\mathrm{ng} / \mathrm{ml}$ with severe asthma, impaired lung function, frequent exacerbations, uncontrollable asthma, and increased use of inhaled steroids and oral steroids cycles in children, such effect implies a wear and tear both economically and in the quality of life ${ }^{8}$. Gupta et al. described VD insufficiency prevalence in $47 \%$ and deficiency in $17 \%$ of asthmatic patients ${ }^{9}$. Regarding allergic rhinitis, even though it shares similar inflammatory mechanisms with allergic asthma, its association with VD levels is less consistent ${ }^{10,11}$.

The objective of this study was to evaluate the prevalence of VD deficiency in patients with respiratory allergies and describe the associated factors.

\section{Material and methods}

\section{Study population}

We conducted a transversal and descriptive study in patients between 3 and 14 years old who attended the allergy and immunology department, who had a recent clinical diagnosis of allergic rhinitis and asthma following ARIA and GINA guidelines. These patients were sensitized to one or more aeroallergen identified by a skin prick tests (Greer ${ }^{\circledR}$ allergens). As immunotherapy guidelines indicate, a positive skin prick test was considered if the wheal was $3 \mathrm{~mm}$ bigger than the negative control. All patients and their parents signed assent and informed consent. The protocol was approved by the Research and Ethics Committee of the Hospital (Approval number DI/6/309/04/013). This study was performed according to the Mexican General Health Law regarding Investigation in human beings and the Helsinki Declaration.

After a confirmed diagnosis of allergic rhinitis or asthma was made, we measured serum VD levels and we investigated the different variables considered to be related to VD levels. The following variables were evaluated: age, gender, BMI, type of birth, and season in which VD levels were taken, skin type according to
Table 1. General characteristics of the study population $(n=63)$

\begin{tabular}{|c|c|}
\hline Females n (\%) & $34(54)$ \\
\hline Age in years, mean $\left(S D^{a}\right)$ & 7 (IOR: 5-9) \\
\hline Weight in kg, mean (SD) & 23.05 (IOR: 19.8-34.5) \\
\hline Body mass index $\left(\mathrm{Kg} / \mathrm{m}^{2}\right)$, mean (SD) & $16.78( \pm 2.76)$ \\
\hline $\begin{array}{l}\text { Vitamin D ng/ml, mean (SD) } \\
\text { Sufficient levels }(\geq 30) n(\%) \\
\text { Insufficient levels }(21-29) n(\%) \\
\text { Deficient levels }(<20) n(\%)\end{array}$ & $\begin{array}{c}23.66( \pm 7.28) \\
14(22.2) \\
30(47.6) \\
19(30.2)\end{array}$ \\
\hline Total serum immunoglobulin E UI/I, mean (SD) & 154 (IOR: 65.1-440) \\
\hline Eosinophils, mean (SD) & 230 (IOR: 200-500) \\
\hline $\begin{array}{l}\text { Type of birth, } \mathrm{n}(\%) \\
\text { Cesarean section } \\
\text { Vaginal delivery }\end{array}$ & $\begin{array}{l}35(55.6) \\
28(44.6)\end{array}$ \\
\hline $\begin{array}{l}\text { Season, n (\%) } \\
\text { Winter } \\
\text { Spring } \\
\text { Autumn }\end{array}$ & $\begin{array}{c}30(47.6) \\
30(47.6) \\
3(4.8)\end{array}$ \\
\hline $\begin{array}{l}\text { Skin type (According to Fitzpatrick) n (\%) } \\
\text { I } \\
\text { II } \\
\text { III } \\
\text { IV } \\
\text { V }\end{array}$ & $\begin{aligned} & 0 \\
2 & (3.2) \\
21 & (33.3) \\
39 & (61.9) \\
1 & (1.6)\end{aligned}$ \\
\hline Sunscreen use, $\mathrm{n}(\%)$ & $17(27)$ \\
\hline $\begin{array}{l}\text { Consumption of food rich in Vitamin D, } \mathrm{n}(\%) \\
\text { Cod liver supplements } \\
\text { Fish } \\
\text { Mushrooms } \\
\text { Egg } \\
\text { Dairy products } \\
\text { Cereals }\end{array}$ & $\begin{array}{l}63(100) \\
4(4.8) \\
44(69) \\
9(14.3) \\
55(87.3) \\
61(96.8) \\
55(87.3)\end{array}$ \\
\hline $\begin{array}{l}\text { Allergic rhinitis } \mathrm{n}(\%) \\
\text { Intermittent mild } \\
\text { Intermittent moderate/severe } \\
\text { Persistent mild } \\
\text { Persistent moderate/severe }\end{array}$ & $\begin{aligned} 63(100) \\
18(28.6) \\
2(3.2) \\
6(9.5) \\
37(58.7)\end{aligned}$ \\
\hline $\begin{array}{l}\text { Asthma, } \mathrm{n}(\%) \\
\text { Controlled } \\
\text { Partially controlled } \\
\text { Uncontrolled }\end{array}$ & $\begin{array}{c}29(46) \\
5(8.0) \\
12(19.0) \\
12(19.0)\end{array}$ \\
\hline $\begin{array}{l}\text { Comorbidities n (\%) } \\
\text { Sinusitis } \\
\text { Allergic conjunctivitis } \\
\text { Atopic dermatitis } \\
\text { Food allergy }\end{array}$ & $\begin{array}{l}20(32) \\
10(50) \\
6(30) \\
3(15) \\
1(5)\end{array}$ \\
\hline
\end{tabular}

aAverages and standard deviation are shown; However, in the variables whose distributions were not normal, medians, and interquartile range are shown.

Fitzpatrick, time of sun exposure, sunscreen use, VD fortified food consumption, drugs that interfere with the metabolism and absorption of VD (systemic steroids, 
Table 2. Patients characteristics according to Vitamin D values

\begin{tabular}{|c|c|c|c|c|}
\hline Variables & $\begin{array}{l}\text { Group I sufficient levels } \\
\qquad(\geq 30)(n=14)\end{array}$ & $\begin{array}{l}\text { Group II insufficient levels } \\
(20-29)(n=30)\end{array}$ & $\begin{array}{c}\text { Group III deficient levels } \\
\qquad<20)(n=19)\end{array}$ & $\mathbf{p}^{*}$ \\
\hline $\begin{array}{l}\text { Age, } n(\%) \\
3-5 \text { years old } \\
6-11 \text { years old } \\
12-14 \text { years old }\end{array}$ & $\begin{array}{c}5(35.7) \\
8(57.1) \\
1(7.2)\end{array}$ & $\begin{array}{c}11(40) \\
17(56.7) \\
1(3.3)\end{array}$ & $\begin{array}{c}2(10.5) \\
12(63.2) \\
5(26.3)\end{array}$ & 0.032 \\
\hline $\begin{array}{l}\text { Sex, n (\%) } \\
\text { Male } \\
\text { Female }\end{array}$ & $\begin{array}{l}5(35.7) \\
9(64.3)\end{array}$ & $\begin{array}{l}14(46.7) \\
16(53.3)\end{array}$ & $\begin{array}{l}10(52.6) \\
9(47.4)\end{array}$ & 0.63 \\
\hline $\begin{array}{l}\text { BMla }\left(\mathrm{Kg} / \mathrm{m}^{2}\right) \text { medium } \\
\text { (Minimun-maximun) }\end{array}$ & $\begin{array}{c}15.80 \\
(13.52-21.66)\end{array}$ & $\begin{array}{c}16.05 \\
(13.22-20.98)\end{array}$ & $\begin{array}{c}17.39 \\
(12.77-26.19)\end{array}$ & 0.29 \\
\hline $\begin{array}{l}\text { Type of birth, } \mathrm{n}(\%) \\
\text { Caesarean section } \\
\text { Normal }\end{array}$ & $\begin{array}{l}8(57.1) \\
6(42.9)\end{array}$ & $\begin{array}{l}17(56.7) \\
13(43.3)\end{array}$ & $\begin{array}{l}10(52.6) \\
9(47.4)\end{array}$ & 0.95 \\
\hline $\begin{array}{l}\text { Season, n (\%) } \\
\text { Winter } \\
\text { Spring } \\
\text { Autumn }\end{array}$ & $\begin{array}{l}6(42.9) \\
7(50) \\
1(7.1)\end{array}$ & $\begin{array}{c}14(46.7) \\
15(50) \\
1(3.3)\end{array}$ & $\begin{array}{c}10(52.6) \\
8(42.1) \\
15.3)\end{array}$ & 0.85 \\
\hline $\begin{array}{l}\text { Skin Type, n (\%) } \\
\text { II } \\
\text { III } \\
\text { IV } \\
\text { V }\end{array}$ & $\begin{array}{c}1(7.1) \\
7(50) \\
6(42.9) \\
0\end{array}$ & $\begin{array}{c}1(3.3) \\
10(33.3) \\
19(63.4) \\
0\end{array}$ & $\begin{array}{c}0 \\
4(21) \\
14(73.7) \\
1(5.3)\end{array}$ & 0.06 \\
\hline $\begin{array}{l}\text { Using sunscreen n (\%) } \\
\text { Medium SPF } 15-29 \\
\text { High SPF } 30-50 \\
\text { Very high SPF > } 50\end{array}$ & $\begin{array}{c}3(31.4) \\
0 \\
0 \\
3(21.4)\end{array}$ & $\begin{array}{c}9(52.9) \\
3(10) \\
4(13.3) \\
2(6.7)\end{array}$ & $\begin{array}{l}5(26.3) \\
1(5.3) \\
2(10.5) \\
2(10.5)\end{array}$ & 0.83 \\
\hline $\lg \mathrm{E}^{\mathrm{b}} \mathrm{Ul} / \mathrm{ml}$, mean (SD) & 304 (297.02) & $360.64(570.45)$ & $460.57(658.15)$ & 0.57 \\
\hline Eosinophils, mean (SD) & $392.85(350.85)$ & $307.67(282.57)$ & $455.26(320.12)$ & 0.23 \\
\hline $\begin{array}{l}\text { Allergic rhinitis } \mathrm{n}(\%) \\
\text { Intermittent mild } \\
\text { Intermittent moderate/severe } \\
\text { Persistent mild } \\
\text { Persistent moderate/severe }\end{array}$ & $\begin{array}{l}4(28.6) \\
1(7.1) \\
2(14.3) \\
7(50)\end{array}$ & $\begin{array}{c}8(26.7) \\
1(3.3) \\
0 \\
21(70)\end{array}$ & $\begin{array}{l}6(31.6) \\
0 \\
4(21.1) \\
9(47.4)\end{array}$ & 1.0 \\
\hline $\begin{array}{l}\text { Asthma, n (\%) } \\
\text { Controlled } \\
\text { Partially controlled } \\
\text { Uncontrolled }\end{array}$ & $\begin{array}{l}2(14.3) \\
2(14.3) \\
2(14.3)\end{array}$ & $\begin{array}{c}3(10) \\
6(20) \\
8(26.7)\end{array}$ & $\begin{array}{c}0 \\
4(21.1) \\
2(10.5)\end{array}$ & 0.226 \\
\hline Comorbidities, n (\%) & $2(14.3)$ & $10(33.3)$ & $8(42.1)$ & 0.235 \\
\hline
\end{tabular}

*p values were calculated using Kruskal-Wallis test, differences were considered statistically significant with $p \leq 0.05$ Abbreviations: aBody mass index was estimated using the WHO Child Growth Standards, 'Immunoglobulin E

anticonvulsants, and antiretrovirals), allergic rhinitis and asthma severity, associated diseases (Sinusitis, allergic conjunctivitis, atopic dermatitis, and food Allergy), total serum immunoglobulin E (IgE), peripheral blood eosinophil count, and $25(\mathrm{OH})$ VD levels.

\section{VD levels}

VD levels were evaluated by the electrochemiluminescence method. Values were reported in $\mathrm{ng} / \mathrm{ml}$. Normal values were between 30 and $100 \mathrm{ng} / \mathrm{ml}$. Patients were divided into three groups according to VD levels: $\geq 30 \mathrm{ng} / \mathrm{ml}$ sufficiency, $21-29 \mathrm{ng} / \mathrm{ml}$ insufficiency, and $<20 \mathrm{ng} / \mathrm{ml}$ deficiency.

\section{Statistical analysis}

It was performed with SPSS v. 24.0. For descriptive statistics of quantitative variables, mean, and standard deviation were used. For categorical variables, frequencies 
and percentages were used. The mean comparison was performed using the Kruskal-Wallis test, and the Chi-square test was used for categorical variables. The odds ratio $(\mathrm{OR})$ with confidence intervals $(\mathrm{Cl})$ of $95 \%$ with $p<0.05$ was estimated.

\section{Results}

\section{Demographic characteristics of the population}

Sixty-three patients were included with a mean age of 7.25 years $( \pm 2.84)$; $34(54 \%)$ were females. The mean weight was $26.7 \mathrm{~kg}( \pm 10.89)$, mean BMl of $16.78 \mathrm{~kg} / \mathrm{m}^{2}$ ( \pm 2.76), and VD mean levels of $23.66 \mathrm{ng} / \mathrm{ml}( \pm 7.28)$, mean total serum $\mathrm{IgE}$ was $378.2 \mathrm{UI} / \mathrm{mL}( \pm 547.65)$, and eosinophils 371.1 cells $/ \mathrm{mL}( \pm 311.6)$. Ninety-five percent of the samples were taken in winter and spring, and the skin type most commonly found was type IV in $61.9 \%$. Twenty-seven percent of the population used some type of sunscreen. All the subjects consumed some food containing VD, milk being the most frequent.

According to inclusion criteria, all the patients had allergic rhinitis, $46 \%$ had asthma, and $32 \%$ had a concomitant disease. Of the patients with concomitant diseases, 50\% had chronic rhinosinusitis, 30\% had allergic conjunctivitis, $15 \%$ had atopic dermatitis, and $5 \%$ had food allergy, as described in table 1 .

As shown in table 2, they were divided into three groups according to VD levels: $14(22.2 \%)$ in Group I with sufficient levels ( $\geq 30)$, $30(47.6 \%)$ in Group II with insufficient levels (21-29), and $19(30.2 \%)$ in Group III with deficient levels $(<20)$.

Table 2 describes each one of the groups' characteristics. VD values show that the patients in Group III had higher BMl values, total serum IgE, and eosinophils. Group III also had more comorbidities, but only observing statistically significant differences in the age and skin type.

Table 3 divides the population into the following categories based on VD enriched food consumption: no consumption versus consumption. Cod liver supplement consumption was common in five patients who had higher VD levels. Table 4 describes the frequency of sun exposure in minutes per day. No statistically significant differences between the groups were observed.

\section{Reason of mummies associated of VD deficiency and insufficiency}

We found that $47.6 \%$ of patients had insufficient VD levels, while $30.15 \%$ had deficient levels, according to the classification mentioned previously.
Table 3. Vitamin D rich foods consumed, n (\%)

\begin{tabular}{|c|c|c|c|c|}
\hline Variables & $\begin{array}{l}\text { Group I } \\
(n=14)\end{array}$ & $\begin{array}{l}\text { Group II } \\
(n=30)\end{array}$ & $\begin{array}{c}\text { Group III } \\
(n=19)\end{array}$ & $\mathbf{p}^{*}$ \\
\hline $\begin{array}{l}\text { Cod liver } \\
\text { supplements } \\
\text { No } \\
\text { Yes }\end{array}$ & $\begin{array}{c}11(78.6) \\
3(21.4)\end{array}$ & $\begin{array}{c}29(96.7) \\
1(3.3)\end{array}$ & $\begin{array}{c}29(96.7) \\
1(3.3)\end{array}$ & 0.02 \\
\hline $\begin{array}{l}\text { Fish } \\
\text { No } \\
\text { Yes }\end{array}$ & $\begin{array}{c}2(14.3) \\
12(85.7)\end{array}$ & $\begin{array}{c}9(30) \\
21(70)\end{array}$ & $\begin{array}{c}8(42.1) \\
11(57.9)\end{array}$ & 0.23 \\
\hline $\begin{array}{l}\text { Mushrooms } \\
\text { No } \\
\text { Yes }\end{array}$ & $\begin{array}{l}12(85.7) \\
2(14.3)\end{array}$ & $\begin{array}{l}27(90) \\
3(10)\end{array}$ & $\begin{array}{c}15(78.9) \\
4(21.1)\end{array}$ & 0.56 \\
\hline $\begin{array}{l}\text { Egg } \\
\text { No } \\
\text { Yes }\end{array}$ & $\begin{array}{c}2(14.3) \\
12(85.7)\end{array}$ & $\begin{array}{c}4(13.3) \\
26(86.7)\end{array}$ & $\begin{array}{c}2(10.5) \\
17(89.5)\end{array}$ & 0.94 \\
\hline $\begin{array}{l}\text { Dairy products } \\
\text { No } \\
\text { Yes }\end{array}$ & $\begin{array}{c}0 \\
14(100)\end{array}$ & $\begin{array}{c}1(3.3) \\
29(96.7)\end{array}$ & $\begin{array}{c}1(5.3) \\
18(94.7)\end{array}$ & 0.69 \\
\hline $\begin{array}{l}\text { Cereals } \\
\text { No } \\
\text { Yes }\end{array}$ & $\begin{array}{c}0 \\
14(100)\end{array}$ & $\begin{array}{c}5(16.7) \\
25(83.3)\end{array}$ & $\begin{array}{c}3(15.8) \\
16(84.2)\end{array}$ & 0.27 \\
\hline
\end{tabular}

*The differences were considered statistically significant with $p \leq 0.05$, these $P$ values were calculated using the Chi-square test.

\section{RISK FACTORS ASSOCIATED WITH VD DEFICIENCY}

The only group that showed a lower risk of VD deficiencies was $3-5$ years old (OR $0.18,95 \%$ IC $0.03-0.91$ ). However, it can be recognized that patients at risk of VD deficiency were those aged 12-14 years old (OR 7.5, 95\% IC 1.306-43.066), those with skin type V (OR 3.444, IC 2.334-5.083 95\%, P 0.125), moderate-severe intermittent rhinitis (OR 1.452, 95\% IC 1.227-1.719), and controlled asthma (OR 1.487, 95\% Cl 1.243-1.780). The lack of consumption of cod liver supplements was associated with deficiency $(\mathrm{OR} 1.475,95 \% \mathrm{Cl}$ 1.237-1.759, p: 0.1), table 5.

We did not find other conditions associated with low levels of VD in any of the patients, such as the use of systemic corticosteroids, antiretrovirals, anticonvulsants, or protein-losing syndromes.

\section{Discussion}

This study shows a VD deficiency of $30.15 \%$, and insufficiency of $47.1 \%$, indicating that only $22.75 \%$ of the study population has sufficient VD levels. These data are superior to those showed by the national health and nutrition survey (ENSANUT) 2006 that reported a VD deficiency of $24.1 \%$ and insufficient of $30 \%$ in children between 2 and 5 years old, and a deficiency 
Table 4. Sun exposure (minutes/day)

\begin{tabular}{|l|c|c|c|c|}
\hline Variables (min) & $\begin{array}{c}\text { Group I sufficient levels }(\geq \mathbf{3 0}) \\
(\mathbf{n}=\mathbf{1 4})\end{array}$ & $\begin{array}{c}\text { Group II insufficient levels (21-29) } \\
(\mathbf{n}=\mathbf{3 0})\end{array}$ & $\begin{array}{c}\text { Group III deficient levels }(<20) \\
(\mathbf{n}=\mathbf{1 9})\end{array}$ & $\mathbf{p}^{*}$ \\
\hline $0-15$ & $2(14.3)$ & $4(13.3)$ & 0 & 0.24 \\
\hline $16-30$ & $2(14.3)$ & $1(3.3)$ & $2(10.5)$ & 0.60 \\
\hline $31-45$ & $1(7.1)$ & 0 & $1(5.3)$ & 0.12 \\
\hline $46-60$ & $1(7.1)$ & $6(20)$ & $2(10.5)$ & 0.55 \\
\hline $61-75$ & 0 & $1(3.3)$ & $1(5.3)$ & 0.69 \\
\hline $76-90$ & $1(7.1)$ & 0 & 0 & 0.17 \\
\hline $91-105$ & $1(7.1)$ & 0 & $7(36.8)$ & 0.17 \\
\hline $106-120$ & $1(7.1)$ & $5(16.3)$ & $6(31.6)$ & 0.19 \\
\hline$>120$ & $5(35.7)$ & $13(43.3)$ & 0.70 \\
\hline
\end{tabular}

*p values were calculated using Kruskal-Wallis test, differences were considered statistically significant with $p \leq 0.05$.

of $10 \%$ and insufficiency of $18 \%$ in children between 6 and 12 years old. This survey was conducted in the general population, unlike our study that included only allergic patients. We found that patients between 12 and 14 years old showed an increased risk of deficiency, unlike the ENSANUT survey, which reported a higher deficiency in the preschool group ${ }^{3}$. BMI was higher in the group of patients with deficiency, but there was no statistically significant difference between the groups and no association, unlike what is reported in the literature, in which it is stated that patients with a higher BMI have lower VD levels. There are different hypotheses that explain deficiency in these subjects such as low sun exposure, poor supplement intake, accumulation into adipose tissue, or more bone mass needed to support the heavy weight ${ }^{12}$.

The season in which VD levels were measures does not show significant differences between groups, and no risk of significant association was found, despite what Webb et al. report, as they observed lower VD levels in the winter months caused by differences in solar radiation during those months. Although, this study was carried out in a Canadian population where solar exposure may be lower in the winter months than in our population ${ }^{13}$.

Significant association was found in types II and V according to Fitzpatrick being greater in the latter. However, we did not explain why skin types being these extremes were associated with the deficiency, different from what Clemens et al. who describe that higher levels of melanin are associated with lower levels of VD due to a decrease in solar absorption in hyper-pigmented skin ${ }^{14}$.
Regarding the use of sunscreen, a greater association with deficiency was found with its use, but the OR did not show a statistically significant association. Matsuoka et al. described that using a sunscreen with a sun protection factor $>15$ decreases VD absorption in the skin up to $99 \%{ }^{15}$.

Higher levels of $\lg E$ and eosinophils were found in patients with VD deficiency, but the OR did not show a significant association. Muehleisen describes the role of $V D$ in the regulation of IgE production, which may explain that low levels of VD produce an imbalance of regulatory $T$ cells and IgE-producing B cells. However, other authors have not been able to find this association ${ }^{16}$.

Regarding the association with allergic rhinitis, there are controversial data some authors have documented a strong relationship between levels of VD and allergic process, for example: Vasallo and Camargo demonstrated that VD deficiencies are associated with low tolerance to environmental allergens ${ }^{17}$. On the other hand, Mai et al. documented that in adult Norwegian patients there is a significant relationship between deficient levels of $\mathrm{VD}$ and the development of allergic rhinitis ${ }^{18}$. Rothers et al. found that deficient levels of VD in umbilical cord blood are associated with aeroallergens and predispose to the development of rhinitis and asthma and even Gupta et al. described that low levels of this vitamin are associated with severe asthma, uncontrolled disease, and airway remodeling ${ }^{19,20}$. By another hand, others researchers found no significative associations between rhinitis and lower levels of $\mathrm{VD}^{8}$. In our case, those patients with persistent disease were associated with the lower VD values without statistical significance, so we 
Table 5. Association between patients characteristics and Vitamin D status

\begin{tabular}{|c|c|c|c|}
\hline Variable & OR & $95 \%$ IC & $\mathbf{p}^{\ddagger}$ \\
\hline $\begin{array}{l}\text { Age, } n(\%) \\
3-5 \text { years old } \\
6-11 \text { years old } \\
12-14 \text { years old }\end{array}$ & $\begin{array}{l}0.18 \\
1.30 \\
7.50\end{array}$ & $\begin{array}{c}0.03-0.91 \\
0.43-3.94 \\
1.30-43.06\end{array}$ & $\begin{array}{l}0.02 \\
0.63 \\
0.03\end{array}$ \\
\hline $\begin{array}{l}\text { Sex } \\
\text { Male } \\
\text { Female }\end{array}$ & $\begin{array}{l}1.46 \\
0.68\end{array}$ & $\begin{array}{l}0.49-4.30 \\
0.23-2.01\end{array}$ & $\begin{array}{l}0.49 \\
0.49\end{array}$ \\
\hline $\begin{array}{l}\text { Body mass index percentile } \\
\text { Under weight } \\
\text { Normal } \\
\text { Overweight } \\
\text { Obesity }\end{array}$ & $\begin{array}{l}0.91 \\
0.71 \\
0.91 \\
0.91\end{array}$ & $\begin{array}{l}0.16-5.20 \\
0.23-2.23 \\
0.16-5.20 \\
0.16-5.20\end{array}$ & $\begin{array}{l}0.92 \\
0.56 \\
0.92 \\
0.92\end{array}$ \\
\hline $\begin{array}{l}\text { Type of birth, } \mathrm{n}(\%) \\
\text { Caesarean section } \\
\text { Vaginal delivery }\end{array}$ & $\begin{array}{l}1.11 \\
0.84\end{array}$ & $\begin{array}{l}0.40-3.48 \\
0.28-2.48\end{array}$ & $\begin{array}{l}0.75 \\
0.75\end{array}$ \\
\hline $\begin{array}{l}\text { Season, n (\%) } \\
\text { Winter } \\
\text { Spring } \\
\text { Autumn }\end{array}$ & $\begin{array}{l}1.33 \\
0.72 \\
1.16\end{array}$ & $\begin{array}{c}0.45-3.92 \\
0.24-2.15 \\
0.09-13.69\end{array}$ & $\begin{array}{l}0.60 \\
0.56 \\
0.90\end{array}$ \\
\hline $\begin{array}{l}\text { Skin type } \\
\text { II } \\
\text { III } \\
\text { IV } \\
\text { V }\end{array}$ & $\begin{array}{l}1.45 \\
0.42 \\
2.12 \\
3.44\end{array}$ & $\begin{array}{l}1.22-1.71 \\
0.12-1.49 \\
0.65-6.94 \\
2.33-5.08\end{array}$ & $\begin{array}{l}0.35 \\
0.17 \\
0.20 \\
0.12\end{array}$ \\
\hline Sunscreen use & 1.05 & $0.31-3.54$ & 0.93 \\
\hline $\begin{array}{l}\text { Immunoglobulin } \mathrm{E}(\mathrm{UI} / \mathrm{l}) \\
\quad 0-165 \\
\geq 166\end{array}$ & $\begin{array}{l}0.55 \\
1.80\end{array}$ & $\begin{array}{l}0.17-1.72 \\
0.58-5.61\end{array}$ & $\begin{array}{l}0.45 \\
0.30\end{array}$ \\
\hline $\begin{array}{l}\text { Eosinophils } \\
0-300 \\
\geq 300\end{array}$ & $\begin{array}{l}0.46 \\
2.14\end{array}$ & $\begin{array}{l}0.15-1.39 \\
0.71-6.42\end{array}$ & $\begin{array}{l}0.16 \\
0.16\end{array}$ \\
\hline $\begin{array}{l}\text { Allergic rhinitis n (\%) } \\
\text { Intermittent mild } \\
\text { Intermittent } \\
\text { moderate/severe } \\
\text { Persistent mild } \\
\text { Persistent } \\
\text { moderate/severe }\end{array}$ & $\begin{array}{l}1.23 \\
1.45 \\
\\
5.60 \\
0.51\end{array}$ & $\begin{array}{c}0.38-3.97 \\
1.22-1.71 \\
0.92-33.77 \\
0.17-1.53\end{array}$ & $\begin{array}{l}0.72 \\
0.34 \\
0.04 \\
0.22\end{array}$ \\
\hline $\begin{array}{l}\text { Asthma, } n(\%) \\
\text { Controlled } \\
\text { Partially controlled } \\
\text { Uncontrolled }\end{array}$ & $\begin{array}{l}1.48 \\
1.20 \\
0.40\end{array}$ & $\begin{array}{l}1.24-1.78 \\
0.31-4.59 \\
0.07-2.03\end{array}$ & $\begin{array}{l}0.12 \\
0.79 \\
0.25\end{array}$ \\
\hline Comorbidities & 1.93 & $0.62-5.98$ & 0.24 \\
\hline $\begin{array}{l}\text { Cod liver supplements } \\
\text { No } \\
\text { Yes }\end{array}$ & $\begin{array}{l}1.47 \\
0.67\end{array}$ & $\begin{array}{l}1.23-1.75 \\
0.56-0.80\end{array}$ & $\begin{array}{l}0.17 \\
0.17\end{array}$ \\
\hline $\begin{array}{l}\text { Sun exposure } \\
<60 \mathrm{~min} \\
61-120 \mathrm{~min} \\
\text { Over } 120 \mathrm{~min}\end{array}$ & $\begin{array}{l}0.56 \\
2.82 \\
0.66\end{array}$ & $\begin{array}{l}0.17-1.86 \\
0.87-9.10 \\
0.21-2.08\end{array}$ & $\begin{array}{l}0.34 \\
0.07 \\
0.48\end{array}$ \\
\hline
\end{tabular}

Odds Ratio (OR), confidence interval (CI), ${ }^{\ddagger}$ differences were considered statistically significant with $\mathrm{p} \leq 0.05$, $\mathrm{p}$ values were calculated using the Chi-square test. cannot establish a proper association between rhinitis severity and VD deficiency. We did not find an association between VD deficiency and asthma severity and in similar way, VD deficiency seems to be associated with higher comorbidities, such as rhinosinusitis ${ }^{21}$. However, we did not find a statistically significant association.

With respect to foods enriched with VD, we found that cod liver supplement consumption is a protective factor for deficiency, which is due to its high content of this vitamin $^{22}$. Holick et al. described that exposure to sunlight is a protective factor for VD deficiency, but we were unable to demonstrate this association ${ }^{6}$.

This study has some limiting, including a small sample size and that it only included children. We could not find a strong association with some variables considered to be important regarding VD levels, but this could have been more evident with a bigger sample. One of problem in this work is that it only included allergic patients so we have an idea of VD deficiency repercussion in this population but the comparison is not complete without a control group. In the future, it could be convenient to include a control group to establish if this condition is related to the allergic conditions in these patients.

VD deficiency is a global public health problem, and patients with allergic rhinitis and asthma show a high either deficiency or insufficiency - even more than the general population. Different studies have shown an association between VD deficiency and severe manifestations of allergic diseases. However, we could not demonstrate that relationship with statistical significance. It seems that consumption of cod liver supplements is a protective factor for deficiency.

The deficiency of VD is high in allergic patients; the factors associated with the deficiency were little consumption of cod liver, age, skin photo type, and moderate-severe rhinitis. It is necessary more works to confirm our findings and to reveal the mechanisms underlying these observations.

\section{Conclusions}

Vitamin $D$ deficiency is frequent in allergic patients due to several factors such as cod liver consumption, age, skin phototype and the presence of moderate-severe allergic rhinitis.

There is a need for similar studies, not only to confirm our findings, but also, those investigating the underlying mechanism by which allergic patients have lower vitamin D levels compared to the rest of the population. 


\section{Acknowledgment}

We would like to thank Nurse Merit Moreno Herrera for her assistance in obtaining blood samples for serum vitamin $D$ level determinations. We are also grateful with Dr. Espiridión Ramos Martínez for his review of this manuscript.

\section{Conflicts of interest}

The authors declare not have conflicts of interest

\section{Funding}

This study received funding by the Research Department at Hospital General de México, "Dr. Eduardo Liceaga", where it was registered (DI/16/309/04/013).

\section{Ethical disclosures}

Protection of human and animal subjects. The authors declare that no experiments were performed on humans or animals for this study.

Confidentiality of data. The authors declare that they have followed the protocols of their work center on the publication of patient data.

Right to privacy and informed consent. The authors declare that no patient data appear in this article.

\section{References}

1. Whiting SJ, Langlois KA, Vatanparast H, Finestone G. The Vitamin D status of Canadians relative to the 2011 dietary reference intakes: an examination in children and adults with and without supplement use. Am $\mathrm{J}$ Clin Nutr. 2011:94:128-35.

2. Holick MF, Binkley NC, Bischoff-Ferrari H, Gordon CM, Hanley DA, Murad $\mathrm{MH}$, et al. Guidelines for preventing and treating Vitamin $\mathrm{D}$ deficiency and insufficiency revisited. J Clin Endocrinol Metab. 2012;97:1153-8.

3. Flores M, Barquera S, Sánchez LM, Lozada A. Concentracionesséricas de Vitamina D Enniñosmexicanos. Cuernavaca, México: Resultados de la ENSANUT 2006 Instituto Nacional de Salud Pública; 2011
4. Ritu G, Gupta A. Vitamin D deficiency in India: prevalence, causalities and interventions. Nutrients. 2014;6:729-75.

5. Dawodu A, Davidson B, Woo JG, Pen YM, Ruiz-Palacios GM, Guerrero ML, et al. Sun exposure and Vitamin D supplementation in relation to Vitamin $D$ status of breastfeeding mothers and infants in the global exploration of human milk study. Nutrients. 2015;7:1081-93.

6. Holick MF, Binkley NC, Bischoff-Ferrari H, Gordon CM, Hanley DA Heaney RP, et al. Evaluation treatment and prevention of Vitamin D deficiency: an endocrine society clinical practice guideline. J Clin Endocrinol Metab. 2011;96:1911-30.

7. Wacker M, Holick MF. Vitamin D-effects on skeletal and extra skeletal health and the need for supplementation. Nutrients. 2013;5:111-48.

8. Yawna J, Lawrence LA, Carroll WW, Mulligan JK. Vitamin D for the treatment of respiratory diseases: is it the end or just the beginning? $\mathrm{J}$ Steroid Biochem Mol Biol. 2015;148:326-37.

9. Gupta A, Bush A, Hawrylowicz C, Saglani S. Vitamin D and asthma in children. Paediatr Respir Rev. 2012;13:236-43.

10. Cheng $\mathrm{MH}, \mathrm{Kim} \mathrm{S}$, Park GH, Chang SE, Bang S, Won $\mathrm{CH}$, et al. Low Vitamin $\mathrm{D}$ levels are associated with atopic dermatitis, but not allergic rhinitis, asthma, or IgE sensitization, in the adult Korean population. $J$ Allergy ClinImmunol. 2014;133:1048-55.

11. Jung JW, Kim JY, Cho SH, Choi BW, Min KU, Kang HR. Allergic rhinitis and serum 25-hydroxyvitamin D level in Korean adults. Ann. Allergy Asthma Immunol. 2013:111:352-7.

12. Antolína SH, García MC, De Frutos VA. Concentracionesdeficientes de Vitamina $D$ enpacientes con obesidadmórbida. Estudio de caso-control. Endocrinol Nutr. 2010:57:256-61.

13. Webb AR, Kline L, Holick MF. Influence of season and latitude on the cutaneous synthesis of Vitamin D3: exposure to winter sunlight in Boston and Edmonton will not promote Vitamin D3 synthesis in human skin. $J$ Clin Endocrinol Metab. 1988;67:373-8.

14. Clemens TL, Adams JS, Henderson SL, Holick MF. Increased skin pigment reduces the capacity of skin to synthesise Vitamin D3. Lancet. 1982;319:74-6.

15. Matsuoka LY, Ide L, Wortsman J, MacLaughlin JA, Holick MF. Sunscreens suppress cutaneous Vitamin D3 synthesis. J Clin Endocrinol Metab. 1987;64:1165-8.

16. Muehleisen $B$, Gallo RL. Vitamin $D$ in allergic disease: shedding light on a complex problem. J Allergy Clinlmmunol. 2013;131:324-9.

17. Vasallo MF, Camargo CA. Potential mechanisms for the hypothesized link between sunshine, Vitamin D, and food allergy in children. J Allergy Clin Immunol. 2010;2:217-22.

18. Mai XM, Chen $Y$, Camargo CA, Langhammer A. Serum 25-hydroxyvitamin $D$ levels and self-reported allergic rhinitis in Norwegian adults the HUNT study. Allergy. 2014;4:488-93.

19. Rothers J, Wright AL, Stern DA, Halonen M, Camargo CA. Cord blood 25-hydroxyvitamin $D$ levels are associated with aeroallergen sensitization in children from Tucson, Arizona. J Allergy Clin Immunol. 2011;5:1093-9.

20. Gupta A, Sjoukes A, Richards D, Banya W, Hawrylowicz C, Bush A, et al. Relationship between serum Vitamin $D$, disease severity and airway remodeling in children with asthma. Am J Respir Crit Care Med. 2011;184:1342-9.

21. Elbistanlı MS, Koçak HE, Güne囚 S, Acipayam H, 『im囚ek M, Canpolat S, et al. Vit $D$ deficiency is a possible risk factor in ARS. Eur Arch Otorhinolaryngol. 2017;274:3391-95.

22. Forsmo S, Fjeldbo SK, Langhammer A. Childhood cod liver oil consumption and bone mineral density in a population-based cohort of peri and postmenopausal women: the Nord-Trøndelag health study. Am J Epidemiol. 2008;167:406-11. 